UDC 336.2

JEL: E62, G28, H29, H39, O11

\section{Valentyna Martynenko}

Candidate of Economics, Associate Professor,

Deputy Director of the Educational and Scientific Institute of Accounting, Analysis and Audit, University of the State Fiscal Service of Ukraine,

Irpin, Ukraine

E-mail: martynenkovv@ukr.net orcid.org/0000-0001-9078-8345

Received: August, 2019

Accepted: September, 2019

DOI:10.31520/2616-7107/2019.3.3-4

(C) Economics. Ecology. Socium, 2019

CC BY-NC 4.0 license

\section{SCENARIO APPROACH IN FORECASTING TAX REVENUES OF THE STATE BUDGET OF UKRAINE}

Introduction. State revenue management stands first in the areas of government regulation, which is provided by the regulation of fiscal policy. It is achieved by optimizing the amount of nationwide taxes and their tax rates, with the least amount of tax evasion. It is also important to ensure the implementation of the budget process, which is based on budget planning and forecasting, the effectiveness criterion of which is the reliability of the forecast. The compulsory component of extrapolation of time series - the most used forecasting method - is the scenario approach, so the research of possibilities of its implementation is relevant.

Aim and tasks. The aim of the article is to introduce a scenario approach in forecasting tax revenues of the state budget of Ukraine. The main tasks set to achieve this aim are: modeling the dependence of tax revenues on macroeconomic indicators; trend analysis and extrapolation of time series of macroeconomic indicators; development of forecast scenarios of state budget revenues from state taxes.

Results. It is proved that comprehensive stimulation of the production of gross value added, especially in the sphere of material production, as a basis for economic growth, will have a positive impact on the growth of output of goods and services, as well as will provide an increase in the revenues from value added tax (VAT) and excise tax to the state budget. Provision at the state level of further growth of the minimum wage and the deployment of social programs, as well as stimulating the legalization of shadow incomes of individuals in order to stimulate incomes of the population will lead to revenue increase from the personal income tax to the state budget. Creating favorable conditions for doing business by creating a business environment free from corruption, legalizing the shadow income of legal entities in order to maximize the profit of gross profit, mixed income will lead to an increase in corporate income tax revenues and subsoil use fee to the state budget of Ukraine.

Conclusions. Over the next 5 years, aggregate tax revenues to the state budget will increase, regardless of the forecast scenario. The largest contribution to tax revenue growth can be provided by excise tax. The dynamics of the remaining taxes will also be increasing. Because the extrapolation of time series and scenario analysis are applied and universal methods of forecasting, they can be used in forecasting tax revenues of both consolidated and local budgets of Ukraine. Prospects for further research of the author will be relevant to these areas.

Keywords: revenue; fiscal policy; forecast; dependence; factor; indicator. 


\section{УДК 336.2 \\ JEL: E62, G28, H29, H39, O11}

\section{Валентина Мартиненко}

Кандидат економічних

наук, доцент, заступник директора Навчальнонаукового інституту обліку, аналізу та аудиту,

Університет державної фіскальної служби України,

Ірпінь, Україна

E-mail: martynenkovv@ukr.net orcid.org/0000-0001-9078-8345

Отримано: Серпень, 2019

Прийнято: Вересень, 2019

DOI:10.31520/2616-7107/2019.3.3-4

(C) Економіка. Екологія. Соціум, 2019 CC BY-NC 4.0 ліцензія

\section{СЦЕНАРНИЙ ПІДХІД У ПРОГНОЗУВАННІ ПОДАТКОВИХ НАДХОДЖЕНЬ ДЕРЖАВНОГО БЮДЖЕТУ УКРАЇНИ}

Вступ. Управління державними доходами займає провідне місце серед напрямів державного регулювання, які забезпечує реалізація фіскальної політики, яка досягається у ході оптимізації кількості загальнодержавних податків та їх податкових ставок, за яких ухиляння від сплати буде найменшим. При цьому важливо також забезпечити виконання бюджетного процесу, в основі якого лежить бюджетне планування і прогнозування, критерієм ефективності якого є достовірність прогнозу. Обов'язковою складовою екстраполяції динамічних рядів - найбільш застосовуваного методу прогнозування - $\epsilon$ сценарний підхід, тому дослідження можливостей його впровадження актуальне.

Мета і завдання. Мета статті полягає у впровадженні сценарного підходу у прогнозування податкових надходжень державного бюджету України. Основними завданнями, поставленими для досягнення мети, є: моделювання залежності податкових надходжень від макроекономічних показників; трендовий аналіз i екстраполяція динамічних рядів макроекономічних показників; розробка прогнозних сценаріїв надходжень до державного бюджету від загальнодержавних податків.

Результати. Доведено, що всебічне стимулювання виробництва валової доданої вартості, насамперед у сфері матеріального виробництва, як основи економічного зростання, позитивно вплине на ріст випуску товарів і послуг, а також забезпечить збільшення надходжень від податку на додану вартість (ПДВ) і акцизного податку до державного бюджету. Забезпечення на державному рівні подальшого зростання мінімальної зарплати та розгортання соціальних програм, а також стимулювання легалізації тіньових доходів фізичних осіб з метою стимулювання доходів населення призведе до збільшення надходжень від податку на доходи фізичних осіб до державного бюджету. Створення сприятливих умов для ведення бізнесу шляхом формування бізнес-середовища, вільного від корупції, легалізація тіньових доходів юридичних осіб з метою максимізації прибутку валового прибутку, змішаного доходу призведе до збільшення надходжень від податку на прибуток підприємств та плати за користування надрами до державного бюджету України.

Висновки. Упродовж найближчих 5 років сукупні податкові надходження до державного бюджету зростатимуть, не залежно від прогнозного сценарію. Найбільший внесок у зростання податкових надходжень може забезпечити акцизний податок. Динаміка решти податків теж буде зростаючою. Оскільки екстраполяція динамічних рядів та сценарний аналіз $\epsilon$ прикладними i універсальними методами прогнозування, їx можливо застосувати у прогнозуванні податкових надходжень як зведеного, так і місцевих бюджетів України. Перспективи подальших розвідок автора стосуватимуться саме цих напрямів.

Ключові слова: доходи; фіскальна політика; прогноз; залежність; фактор; показник. 
Introduction. Among the areas of state regulation provided by the implementation of fiscal policy, state revenues management stands first. Ensuring an increase in tax revenues to the state budget is the main aim of fiscal policy, which is achieved during the establishment of a small number of national taxes, their optimal tax rates, at which the evasion will be minimal. Another important area of fiscal policy is to ensure the budget process, which is based on budget planning and forecasting. As the criterion for the effectiveness of forecasting results is considered to be the accuracy of the forecast, the impact of macroeconomic conditions must be taken into account in forecasting tax revenues. Another aspect of forecasting reliability is the scenario approach, which is a necessary attribute of extrapolation of time series - the most used forecasting method. That is why the implementation of the scenario approach in forecasting tax revenues to the budget is a relevant direction for improving fiscal policy.

Analysis recent research and publications. The basic theoretical and methodological principles and applied aspects of tax revenue forecasting are devoted the works of foreign scientists and economists such as Hannon et al. (2016), who have researched the tax revenue forecasting errors of the Irish Department of Finance for the period 19972014 [1]; Jochimsen \& Lehmann (2017), who have studied the tax revenue forecasting indicators of the Department of Finance for the period 1997-2014. Some economists have done the empirical analysis of national tax revenue forecasts in OECD countries and proved the lack of influence of political business cycles on forecasting results [2]; Streimikiene, Ahmed, Vveinhardt, Ghauri \& Zahid (2018), who have implemented forecasting Pakistan's tax revenues using time series methods [3]; Molapo et al. (2019), who have suggested using the Bayesian vector-based automatic regression method to forecast tax revenue in South Africa [4]; Mauler (2019), who has examined the impact of tax analysts' forecasts on firms' behavior and investment decisions [5]; as well as Ukrainian scientists - Krasnokutska \& Fadeyev (2016), who have suggested methodological approach to forecasting revenue from the personal income tax to the local budget on the basis of correlation-regression analysis taking into account the trends of change in the gross regional product [6]; Ivanchenko (2017), who has identified the place of medium-term forecasting in Ukraine on the way to the implementation of medium-term budgetary planning [7], Khomutenko \& Bzova (2017), who have implemented forecasting the amount of corporate income tax revenues to the state budget of Ukraine using the method of correlation-regression analysis [8]; Pasichniy (2017), who, using correlation-regression equations, has estimated the influence of the main factors on the dynamics of VAT revenues, income tax, personal income tax and excise tax [9]; Vasilieva (2019), who has summarized scientific ideas on the theoretical aspects of tax forecasting and planning as integral mechanisms of state tax policy [10]; Dubrovina et al. (2019), who have examined the main trends of tax revenues and social contributions in EU countries and estimated the share of total tax revenues (including social contributions) in GDP in EU countries [11]; Chugunov \& Makohon (2019), who have identified the leading role of fiscal strategy in ensuring macroeconomic stability and accelerating economic growth [12] and others.

The given research is dedicated to the study of prospects of implementing the scenario approach in forecasting tax revenues as a tool of fiscal policy, which still remains a poorly researched problem, and has been started by this author in papers [13-14].

Aim and tasks. The aim of the article is to introduce the scenario approach in forecasting tax revenues of the state budget of Ukraine.

Results. In forecasting tax revenues of the state budget of Ukraine, it is advisable to take into account the influence of key macroeconomic factors on the dynamics of major budget-forming taxes:

- Gross value added tax on VAT;

- output of goods and services at basic prices for excise tax revenue;

- import of goods and services for import duties;

- annual income of the population and tax rate on income from the personal income tax;

- gross profit, mixed income and tax rate on corporate income tax;

- gross profit, mixed income for subsoil use fees. 
The results of formalization of the impact of macroeconomic factors on revenues from budgetary taxes to the state budget of Ukraine are shown in Table 1.

Table 1. Results of formalization of degree dependencies* of the main tax revenues to the state budget of Ukraine on macroeconomic indicators

\begin{tabular}{|l|c|c|c|c|c|c|}
\hline \multirow{2}{*}{ Factor value } & \multicolumn{5}{|c|}{ Resulting value, million UAH } \\
\cline { 2 - 8 } & VAT & $\begin{array}{c}\text { Excise } \\
\text { tax }\end{array}$ & $\begin{array}{c}\text { Import } \\
\text { duty }\end{array}$ & $\begin{array}{c}\text { Income } \\
\text { tax }\end{array}$ & $\begin{array}{c}\text { Corporate } \\
\text { income tax }\end{array}$ & $\begin{array}{c}\text { Subsoil } \\
\text { use fee }\end{array}$ \\
\hline Constant & 11,836 & 0,145 & 67,7 & $2 \cdot 10^{-19}$ & 116,05 & 0,0003 \\
\hline Gross value added at basic prices, billion UAH & 1,304 & $\mathrm{x}$ & $\mathrm{x}$ & $\mathrm{x}$ & $\mathrm{x}$ & $\mathrm{x}$ \\
\hline $\begin{array}{l}\text { Production of goods and services at basic prices, } \\
\text { billion UAH }\end{array}$ & $\mathrm{x}$ & 1,54 & $\mathrm{x}$ & $\mathrm{x}$ & $\mathrm{x}$ & $\mathrm{x}$ \\
\hline Imports of goods and services, billion UAH & $\mathrm{x}$ & $\mathrm{x}$ & 0,8 & $\mathrm{x}$ & $\mathrm{x}$ & $\mathrm{x}$ \\
\hline Annual population income, billion UAH & $\mathrm{x}$ & $\mathrm{x}$ & $\mathrm{x}$ & 2,69 & $\mathrm{x}$ & $\mathrm{x}$ \\
\hline Personal income tax rate, $\%$ & $\mathrm{x}$ & $\mathrm{x}$ & $\mathrm{x}$ & 11,19 & $\mathrm{x}$ & $\mathrm{x}$ \\
\hline Gross profit, mixed income, billion UAH & $\mathrm{x}$ & $\mathrm{x}$ & $\mathrm{x}$ & $\mathrm{x}$ & 0,63 & 2,66 \\
\hline Corporate income tax rate, $\%$ & $\mathrm{x}$ & $\mathrm{x}$ & $\mathrm{x}$ & $\mathrm{x}$ & 0,64 & $\mathrm{x}$ \\
\hline $\mathrm{R}^{2}$ & 0,960 & 0,946 & 0,773 & 0,925 & 0,680 & 0,881 \\
\hline F-test & 287,4 & 209,5 & 40,8 & 24,8 & 11,7 & 88,9 \\
\hline F-critical & 4,747 & 4,747 & 4,747 & 3,982 & 3,982 & 4,747 \\
\hline
\end{tabular}

$* y=\beta_{0} \cdot x_{1}^{\beta_{1}} \cdot x_{2}^{\beta_{2}} \cdot \ldots \cdot x_{n}^{\beta_{n}}$, where $y-i$ is the resulting value; $x_{1}, x_{2}, \ldots, x_{n}-$ are the factor values that number from 1 to $n ; \beta_{1}, \beta_{2}, \ldots, \beta_{n}$-are the equation parameters, or regression coefficients, or elasticity coefficients, which show how many \% the resulting value will change when the corresponding factor value increases by $1 \%$; $\beta_{0}-i$ is the constant (the value of the resulting value when the parameters of equation are equal to 0).

Source: author's calculations according to the State Statistics Service of Ukraine [15] and the State Treasury Service of Ukraine [16], formed for 2004-2017.

From the data given in Table 1, it can be seen that the obtained degree dependences are statistically significant and reliable, since the observed values of the $F$ criterion exceed the critical several times, all the coefficients of determination R2 $>0,5$. The economic interpretation of the models is as follows:

$-1 \%$ increase in gross value added causes $1.3 \%$ increase in VAT revenues from the state budget;

- when the output of goods and services at basic prices increases by $1 \%$, the amount of excise tax revenues to the state budget increases by $1.5 \%$;

- increase of import of goods and services by $1 \%$ leads to increase of revenues to the state budget from import duty by $0,8 \%$;

- with annual income growth of population by $1 \%$ the volume of revenue from the personal income tax increases by $2,7 \%$, the increase of the tax rate by $1 \%$ causes the increase of the revenue from the personal income tax to local budgets by $11,2 \%$;
- with 1\% increase in gross profit, mixed income, the corporate income tax revenue increases by $0.6 \%, 1 \%$ tax rate increase causes $0.6 \%$ increase in corporate income tax revenues to the local budgets;

- as gross profit and mixed income increase by $1 \%$, the amount of revenues from subsoil use fee to local budgets increases by $2.7 \%$.

Therefore, the forecasting of tax revenues of the state budget of Ukraine will be implemented on the basis of the parameters of degree dependencies given in Table. 1, taking into account the results of extrapolation of time series of factor values.

5-year forecasts of macroeconomic factors introduced in the model of tax revenues to the state budget of Ukraine were made by the method of extrapolation of time series using the MS Excel-2016 "Forecast sheet" Add-in, which allows to obtain 3 values of the forecast indicator - the first based on the trend equation, the second based on upper confidence interval as maximum and third based on lower 
confidence interval as minimum. Extrapolation as a forecasting method is based on a trend analysis - mathematical formalization of an existing trend of a time series or a dynamic series (a set of numerical values of an indicator at the same intervals of time - levels of a dynamic series, formed over a certain period, i.e. the length of the dynamic series) can be written as follows:

$$
y_{1}, y_{2}, \ldots, y_{t}
$$

where $t-$ is the ordinal number of the dynamic series, when $t=\overline{1 ; n}, n-$ is the number of members of the dynamic series [17, c. 400].

Then the trend function in general will look as follows:

$$
\hat{y}_{t}=f\left(t_{1}, t_{2}, \ldots, t_{n}\right) .
$$

Another important component of trend analysis is the establishment of confidence intervals as an effective means of safeguarding the forecast against uncertainty. This determines the maximum range of variation of the forecast indicator, taking into account the trend equation and the fluctuations of the observed values of the dynamic series. To calculate the fluctuation limits of the observed forecast value from the trend, a standard error of the forecast value of the trend function is calculated $\left(S_{e}\right)$ :

$$
S_{e}=\sqrt{\frac{\sum_{t=1}^{n}\left(y_{t}-\hat{y}_{t}\right)^{2}}{n-2}},
$$

where $y_{t}$ and $\hat{y}_{t}-$ are correspondently the values of actual and calculated by the trend equation of members of the dynamic series; $n-$ is the number of members of the dynamic series $[18$, c. 803$]$.

In the trend analysis, confidence intervals are set taking into account the double standard error of the corresponding forecast value. The lower confidence interval of the corresponding forecast value of the studied indicator is calculated by the formula:

$$
\hat{y}_{t+L}-2 S_{e},
$$

where $\hat{y}_{t+L}-$ is the forecast value of indicator, calculated by the trend equation in each $L$ period of the forecast;

$L-$ is the ordinal number of the forecast year, when $L=\overline{n+1 ; n+m}, \quad m-$ is the number of members of the forecast period.

The upper confidence interval of the forecast is calculated by the formula:

$$
\hat{y}_{t+L}+2 S_{e} \text {. }
$$

Then it can be stated that the forecast value of the indicator is $95 \%$ likely to fall within confidence intervals:

$$
\hat{y}_{t+L} \in\left[\hat{y}_{t+L}-2 S_{e} ; \hat{y}_{t+L}+2 S_{e}\right]
$$

5 -year forecasts of macroeconomic factors are built according to formulas (1-6). On the basis of the obtained results, we will form a

\begin{tabular}{|c|c|c|c|c|c|c|c|}
\hline \multirow{2}{*}{ Indicator name } & \multirow{2}{*}{$\begin{array}{l}\text { Confidence } \\
\text { interval }\end{array}$} & \multicolumn{5}{|c|}{ Indicator values by years: } & \multirow{2}{*}{$\begin{array}{l}2022 \text { in } \% \\
\text { to } 2017\end{array}$} \\
\hline & & 2018 & 2019 & 2020 & 2021 & 2022 & \\
\hline \multirow{3}{*}{$\begin{array}{l}\text { 1. Gross value added at basic } \\
\text { prices }\end{array}$} & lower & 2116,4 & 2224,3 & 2335,6 & 2449,5 & 2565,5 & 101,8 \\
\hline & trend & 2430,1 & 2575,2 & 2720,2 & 2865,3 & 3010,3 & 119,5 \\
\hline & upper & 2743,9 & 2926,1 & 3104,8 & 3281 & 3455,1 & 137,1 \\
\hline \multirow{3}{*}{$\begin{array}{l}\text { 2. Output of goods and } \\
\text { services at basic prices }\end{array}$} & lower & 6142,9 & 6978,7 & 7613,8 & 8108,2 & 8495,2 & 135,8 \\
\hline & trend & 7005,6 & 8198,1 & 9390,6 & 10583,1 & 11775,7 & 188,2 \\
\hline & upper & 7868,2 & 9417,5 & 11167,4 & 13058 & 15056,2 & 240,7 \\
\hline \multirow{3}{*}{$\begin{array}{l}\text { 3. Import of goods and } \\
\text { services }\end{array}$} & lower & 1633,9 & 1864,2 & 2032,4 & 2157,0 & 2248,4 & 135,3 \\
\hline & trend & 1900,8 & 2241,5 & 2582,1 & 2922,8 & 3263,4 & 196,3 \\
\hline & upper & 2167,8 & 2618,8 & 3131,9 & 3688,5 & 4278,4 & 257,4 \\
\hline \multirow{3}{*}{$\begin{array}{l}\text { 4. Annual income of } \\
\text { population }\end{array}$} & lower & 2173,8 & 2420,2 & 2629,1 & 2803,0 & 2948,3 & 111,2 \\
\hline & trend & 2516,3 & 2803,0 & 3089,7 & 3376,4 & 3663,1 & 138,1 \\
\hline & upper & 2858,8 & 3185,8 & 3550,3 & 3949,8 & 4377,9 & 165,1 \\
\hline \multirow{3}{*}{ 5. Gross profit, mixed income } & lower & 931,8 & 1003,9 & 1076,2 & 1148,7 & 1221,3 & 90,7 \\
\hline & trend & 1197,8 & 1278,2 & 1358,5 & 1438,9 & 1519,3 & 112,9 \\
\hline & upper & 1463,7 & 1552,4 & 1640,8 & 1729,1 & 1817,2 & 135,0 \\
\hline
\end{tabular}
summary Table 2 of forecast values of macroeconomic factors of budget-forming taxes.

Table 2. Results of forecasting macroeconomic factors

of budget-forming taxes for 2018-2022, billion UAH

Source: author's calculations. 
The data given in the table 2 illustrate the increasing forecast dynamics of the studied indicators over the next 5 years. Thus, if the dynamics tendencies that were characteristic of the analyzed indicators during 2004-2017 remain, the gross value added will increase by UAH 491 billion $(+19.5 \%)$ at the end of 2022 , and the output of goods and services at basic prices - by UAH 5520 billion $(+88.2 \%)$, imports of goods and services - by UAH 1601 billion $(+96.3 \%)$, annual income of population - by UAH 1011 billion (+ 38.1\%), gross profit, mixed income by UAH 173.4 billion $(+12.9 \%)$.

Under the worst economic conditions and macroeconomic conditions caused by, for example, economic crisis or other socioeconomic problems, the forecast dynamics of the analyzed indicators at the end of 2022 will be as follows: gross value added may increase by UAH 46 billion $(+1.8 \%)$, output of goods and services at basic prices may increase by UAH 2240 billion ( $+35.8 \%$ ), imports of goods and services may increase by UAH 586.3 billion $(+35.3 \%)$, annual income of population may increase by UAH 296.2 billion ( $+11.2 \%$ ), the volume of gross profit, mixed income may decrease by UAH 124.6 billion (-9.3\%).

Under the most favorable economic conditions and macroeconomic conditions, the forecast dynamics of the analyzed indicators at the end of 2022 will be: +935.5 UAH billion or
$+37.1 \%$ of the gross value added; $+8801 \mathrm{UAH}$ billion or $+141 \%$ of output of goods and services at basic prices; +2616 UAH billion or $+157.4 \%$ of the volume of imports of goods and services; +1726 UAH billion or $+65 \%$ of annual income of population; +471.3 UAH billion or $+35 \%$ of gross profit, mixed income.

As it can be seen from the data in Table 2, to research the factors of influence, the tax rates of 2 nationwide taxes were also taken - the personal income tax and the corporate income tax, which the forecast was not made for. It should be noted that in forecasting the revenues from these taxes to the state and local budgets were taken the optimal tax rates obtained by the author while maximizing the state tax revenue by the Dupuy-Laffer Curve: the personal income tax rate $-26 \%$, the corporate income tax rate $-19 \%$ [14, p. 82-83]. Thus, having developed 5-year forecasts of macroeconomic indicators, which have the most significant impact on the tax sources of formation of the state budget revenues, we proceed directly to the forecasting of tax revenues using the parameters of degree dependencies (Table 1) and forecasts (Table 2). It should be noted that an important tool in forecasting will be the scenario approach. The forecast scenarios of tax revenues to the state budget are summarized in Table 3.

Table 3. The forecast scenarios of tax revenues to the state budget for 2018-2022, million UAH

\begin{tabular}{|c|c|c|c|c|c|c|c|}
\hline \multirow{2}{*}{ Indicator } & \multirow{2}{*}{ Forecast scenario } & \multicolumn{5}{|c|}{ Indicator values by years: } & \multirow{2}{*}{$\begin{array}{c}2022 \text { in \% } \\
\text { to } 2017\end{array}$} \\
\hline & & 2018 & 2019 & 2020 & 2021 & 2022 & \\
\hline \multirow{3}{*}{ 1. VAT } & pessimistic & 256916,0 & 274121,5 & 292145 & 310863,2 & 330193,7 & 105,2 \\
\hline & realistic & 307659,5 & 331817,7 & 356393,3 & 381370,7 & 406735,5 & 129,5 \\
\hline & optimistic & 360438,9 & 391960,6 & 423471,6 & 455067,5 & 486804,9 & 155,0 \\
\hline \multirow{3}{*}{ 2. Excise tax } & pessimistic & 98959,8 & 120441,7 & 137731,8 & 151745,4 & 163039,4 & 150,6 \\
\hline & realistic & 121157,2 & 154342,3 & 190246,4 & 228704,3 & 269578,8 & 248,9 \\
\hline & optimistic & 144883,8 & 191086,1 & 248436,6 & 316096,5 & 393593,9 & 363,5 \\
\hline \multirow{3}{*}{ 3. Import duty } & pessimistic & 25186,9 & 27988,7 & 29991,1 & 31453,9 & 32515,5 & 136,1 \\
\hline & realistic & 28428,0 & 32435,4 & 36322,2 & 40107,5 & 43805,4 & 183,3 \\
\hline & optimistic & 31579,1 & 36734,1 & 42387,2 & 48313,8 & 54402,2 & 227,6 \\
\hline \multirow{3}{*}{ 4. Income tax } & pessimistic & 52025,8 & 69450,0 & 86772,8 & 103090,8 & 118104,6 & 157,4 \\
\hline & realistic & 77118,0 & 103089,0 & 133962,2 & 170078,6 & 211769,2 & 282,2 \\
\hline & optimistic & 108703,6 & 145465,2 & 194681,4 & 259353,5 & 342064,7 & 455,9 \\
\hline \multirow{3}{*}{$\begin{array}{l}\text { 5. Corporate } \\
\text { income tax }\end{array}$} & pessimistic & 66697,2 & 69482,5 & 72203,8 & 74866,1 & 67519,3 & 100,9 \\
\hline & realistic & 56939,1 & 59676,9 & 62349,3 & 64961,9 & 77473,9 & 115,8 \\
\hline & optimistic & 75678,2 & 78533,2 & 81322,9 & 84052,5 & 86726,5 & 129,6 \\
\hline \multirow{3}{*}{ 6. Subsoil use fee } & pessimistic & 19708,9 & 24031,3 & 28913,9 & 34385,5 & 40474,4 & 92,3 \\
\hline & realistic & 38433,9 & 45681,0 & 53725,5 & 62600,2 & 72337,1 & 164,9 \\
\hline & optimistic & 65518,0 & 76606,2 & 88770,9 & 102048,8 & 116475,5 & 265,5 \\
\hline \multirow{3}{*}{$\begin{array}{l}\text { Total tax revenues } \\
\text { to the state budget }\end{array}$} & pessimistic & 535951 & 604802 & 670114 & 732073 & 793664 & 106,2 \\
\hline & realistic & 609074 & 703363 & 806067 & 917399 & 1039883 & 139,2 \\
\hline & optimistic & 784228 & 917714 & 1076305 & 1262074 & 1480068 & 198,1 \\
\hline
\end{tabular}

Source: author's calculations. 
The data given in the table 3 illustrate the increasing forecast dynamics of state budget revenues from nationwide taxes over the next 5 years. Thus, under the realistic scenario, if the dynamics tendencies that were characteristic of the analyzed macroeconomic indicators during 2004-2017 remain, the VAT revenues will increase by UAH 92.8 billion at the end of $2022(+29.5 \%)$, from excise tax by UAH 161.3 billion $(+148.9 \%)$, from import duty - by UAH 19.9 billion $(+83.3 \%)$, from personal income tax - by UAH 136.7 billion $(+355.9 \%)$, from the corporate income tax by UAH 10.6 billion $(+29.6 \%)$, from the subsoil use fee - by UAH 28.5 billion $(+64.9 \%)$.

Under the pessimistic scenario, which implies an economic decrease, and decline of macroeconomic conditions, aggravating of socio-economic problems, the forecast dynamics of tax revenues to the state budget of Ukraine at the end of 2022 will be as follows: the amount of revenues to the state budget of Ukraine from VAT will increase by UAH 16.2 billion $(+5.2 \%)$, from excise tax by UAH 54.7 billion $(+50.6 \%)$, from import duty - by UAH 8.6 billion $(+36.1 \%)$, from personal income tax - by UAH 43.1 billion $(+57.4 \%)$, from corporate income tax - by UAH 607 million $(+0.9 \%)$, from subsoil use fee - will decrease by 3.4 billion $(-7.7 \%)$.

Under the optimistic scenario, which implies economic growth, favorable macroeconomic conditions, improvement of welfare of citizens, the estimated dynamics of tax revenues to the state budget of Ukraine at the end of 2022 will be: +172.8 UAH billion or $+55 \%$ of VAT revenues; $+285.3 \mathrm{UAH}$ billion or $+263.5 \%$ of excise tax revenues; +30.5 UAH billion or $+127.6 \%$ of import duties; +267 UAH billion or $+356 \%$ of personal income tax revenue; $+19.8 \mathrm{UAH}$ billion or $+29.6 \%$ of corporate income tax revenue; $+72.6 \mathrm{UAH}$ billion or $+165.5 \%$ of subsoil use fees revenue.

Conclusions. Therefore, according to the results of the research, we can draw the following conclusions.

Firstly, the impact of macroeconomic factors by modeling degree dependencies was taken into account in forecasting tax revenues to the state budget.

Secondly, extrapolation of time series is performed to obtain forecast values of factor values with confidence intervals.

Thirdly, a scenario approach is introduced in forecasting the tax revenues of the state budget of Ukraine, which results in the justification that over the next 5 years the total tax revenues to the state budget will increase, regardless of the forecast scenario: an increase will be from $+6.2 \%$ or $+46,5$ billion UAH (pessimistic scenario) to $+98.1 \%$ or +733 billion UAH (optimistic scenario).

Fourthly, it is proved that the largest contribution to the increase in tax revenues can be provided by excise tax (increase from +50.6 to $+263.5 \%$ ) and personal income tax (increase from +57.4 to $+55.9 \%$ ), but only subsoil use revenues can be decreased by $7.7 \%$ under the pessimistic scenario, with the increasing dynamics of the rest of the taxes.

Fifthly, the methodological approaches of extrapolation of time series and scenario analysis are applied and universal, which allows to apply them to the forecasting of tax revenues of both consolidated and local budgets of Ukraine, - and further author's research will concern the prospects of these directions. 


\section{REFERENCES}

1. Hannon, A., Leahy, E. \& O'Sullivan, R. (2016). An analysis of tax forecasting errors in Ireland. Economic and Social Review, 47(3), 391-423.

2. Jochimsen, B. \& Lehmann, R. (2017). On the political economy of national tax revenue forecasts: evidence from OECD countries. Public Choice, 170(3-4), 211-230. DOI: https://doi.org/10.1007/s11127-016-0391-y.

3. Streimikiene, D., Ahmed, R. R., Vveinhardt, J., Ghauri, S. P. \& Zahid, S. (2018). Forecasting tax revenues using time series techniques - a case of Pakistan. Economic Research Ekonomska Istraživanja, 31(1), 722-754. DOI: https://doi.org/10.1080/1331677X.2018.1442236.

4. Molapo, M. A., Olaomi, J. O. \& Ama N. (2019). Bayesian vector auto-regression method as an alternative technique for forecasting South African tax revenue. Southern African Business Review, 23, 1-28. DOI: https://doi.org/10.25159/1998-8125/4416.

5. Mauler, L. M. (2019). The Effect of analysts' disaggregated forecasts on investors and managers: evidence using pre-tax forecasts. The Accounting Review, 94(3), 279-302. DOI: https://doi.org/10.2308/accr-52268.

6. Krasnokutska, N. S. \& Fadeyeva, A. N. (2016). Forecasting revenues from personal income to the income of the local budget. Bulletin of NTU "KHPI". Series: Actual problems of management and financial-economic activity of the enterprise, 24(1196), 52-55 [in Ukrainian].

7. Ivanchenko, D. I. (2017). Economic-mathematical methods of the medium-term forecasting of value added tax in Ukraine. Ekonomika ta derzhava, 7, 88-93 [in Ukrainian].

8. Khomutenko, A. V. \& Bzova, Yu. I. (2017). Revenue forecasting corporate income tax to the state budget of Ukraine by correlation and regression analysis. Naukovyi visnyk Odeskoho natsionalnoho ekonomichnoho universytetu, 1-2 (243-244), 133-144 [In Ukrainian].

9. Pasichniy, M. D. (2017). Medium-term planning and forecasting in the system of fiscal relation. University Economic Bulletin, 33(1), 361-368 [in Ukrainian].

10. Vasilieva, L. M. (2019). The teoretical aspects of tax forecasting and planning as nongovernmental mechanisms of the state tax policy. Publichne upravlinnia ta mytne administruvannia, 1(20), 31-36. DOI: https://doi.org/10.32836/2310-9653-2019-1-31-36 [In Ukrainian].

11. Dubrovina, N., Neubauerova, E., Kolupaieva, I., Borysova, A., \& Shabanov, R. (2019). Exploring the nexus between tax revenue trends and social contributions development in European Union countries. Financial and Credit Activity: Problems of Theory and Practice, 2(29), 498-508. doi: http://dx.doi.org/10.18371/fcaptp.v2i29.172360.

12. Chugunov, I. \& Makohon, V. (2019). Fiscal strategy as an instrument of economic growth. Baltic Journal of Economic Studies, 5(3), 213-217. DOI: http://dx.doi.org/10.30525/22560742/2019-5-3-213-217.

13. Martynenko, V. V. (2018). On the problem of tax system optimization in Ukraine. Scientific Bulletin of Polissia, 2(14), part 2, 129-134. DOI: https://doi.org/10.25140/2410-95762018-2-2(14)-129-134.

14. Martynenko, V. V. (2018). Features of optimization of direct taxation taking into account the effect of Dupuit-Laffer. Economies' Horizons, 3(6), 78-85. DOI : https://doi.org/10.31499/2616-5236.3(6).2018.156321 [in Ukrainian].

15. State Treasury Service of Ukraine (2019). Reporting on budget execution (revenue). Retrieved from https://www.treasury.gov.ua/ua [In Ukrainian].

16. State Statistics Service of Ukraine (2019). National accounts. Retrieved from http://www.ukrstat.gov.ua/ [in Ukrainian].

17. Nakonechnyi, S. I., Tereshchenko, T. O. \& Romaniuk, T. P. (2004). Ekonometriia. Kyiv: KNEU [in Ukrainian].

18. Mur, Dzh. Kh. \& Uederford, L. R. (2004). Economic modeling in Microsoft Excel. Moscow, Izdatel'skiy dom "Vil'yams" [in Russian]. 